\title{
Response of ice cover on shallow lakes of the North Slope of Alaska to contemporary climate conditions (1950-2011): radar remote-sensing and numerical modeling data analysis
}

\author{
C. M. Surdu ${ }^{1}$, C. R. Duguay ${ }^{1}$, L. C. Brown ${ }^{2}$, and D. Fernández Prieto ${ }^{3}$ \\ ${ }^{1}$ Department of Geography \& Environmental Management and Interdisciplinary Centre on Climate Change (IC ${ }^{3}$ ), University \\ of Waterloo, Waterloo, Canada \\ ${ }^{2}$ Climate Research Division, Environment Canada, Toronto, Canada \\ ${ }^{3}$ EO Science, Applications and Future Technologies Department, European Space Agency (ESA), ESA-ESRIN, Frascati, Italy \\ Correspondence to: C. M. Surdu (csurdu@uwaterloo.ca)
}

Received: 24 June 2013 - Published in The Cryosphere Discuss.: 26 July 2013

Revised: 8 January 2014 - Accepted: 9 January 2014 - Published: 30 January 2014

\begin{abstract}
Air temperature and winter precipitation changes over the last five decades have impacted the timing, duration, and thickness of the ice cover on Arctic lakes as shown by recent studies. In the case of shallow tundra lakes, many of which are less than $3 \mathrm{~m}$ deep, warmer climate conditions could result in thinner ice covers and consequently, in a smaller fraction of lakes freezing to their bed in winter. However, these changes have not yet been comprehensively documented. The analysis of a $20 \mathrm{yr}$ time series of European remote sensing satellite ERS- $1 / 2$ synthetic aperture radar (SAR) data and a numerical lake ice model were employed to determine the response of ice cover (thickness, freezing to the bed, and phenology) on shallow lakes of the North Slope of Alaska (NSA) to climate conditions over the last six decades. Given the large area covered by these lakes, changes in the regional climate and weather are related to regime shifts in the ice cover of the lakes. Analysis of available SAR data from 1991 to 2011, from a sub-region of the NSA near Barrow, shows a reduction in the fraction of lakes that freeze to the bed in late winter. This finding is in good agreement with the decrease in ice thickness simulated with the Canadian Lake Ice Model (CLIMo), a lower fraction of lakes frozen to the bed corresponding to a thinner ice cover. Observed changes of the ice cover show a trend toward increasing floating ice fractions from 1991 to 2011, with the greatest change occurring in April, when the grounded ice fraction declined by $22 \%(\alpha=0.01)$. Model results indicate a trend toward thinner ice covers by $18-22 \mathrm{~cm}$ (no-snow and
\end{abstract}

$53 \%$ snow depth scenarios, $\alpha=0.01)$ during the 1991-2011 period and by $21-38 \mathrm{~cm}(\alpha=0.001)$ from 1950 to 2011 . The longer trend analysis (1950-2011) also shows a decrease in the ice cover duration by $\sim 24$ days consequent to later freeze-up dates by 5.9 days $(\alpha=0.1)$ and earlier break-up dates by $17.7-18.6$ days $(\alpha=0.001)$.

\section{Introduction}

Lake ice cover has been shown to be a robust indicator of climate variability and change. Previous studies have identified lake ice as a highly sensitive cryospheric component to climate conditions (Schindler et al., 1990; Robertson et al., 1992; Heron and Woo, 1994; Vavrus et al., 1996; Walsh et al., 1998; Magnuson et al., 2000; Hodgkins et al., 2002; Assel et al., 2003; Bonsal et al., 2006; Duguay et al., 2006). Climatedriven changes have significantly impacted high-latitude environments over recent decades, changes that are predicted to continue or even accelerate in the near future as projected by global climate models (Overland et al., 2011; Dufresne et al., 2013; Koenigk et al., 2013). With projected amplified warming of polar regions, the ice cover of shallow Arctic lakes is expected to continue reducing in both thickness and duration. Although the response of lakes may be heterogeneous depending on latitude, lake depth and size, water composition and water dynamics, the majority of lakes demonstrate an overall strong response to surface air temperatures (Palecki 
and Barry, 1986). Persistent warmer air temperatures (Serreze et al., 2000; Trenberth et al., 2007) and increased snowfall observed in the Arctic over the last decades (Jones et al., 2011; Arp et al., 2012), associated with amplified reduction of sea-ice concentrations, thickness and extent (Serreze et al., 2007; Comiso et al., 2008; Walsh et al., 2011), have accelerated during recent years (Walsh et al., 2011). These changes in the Arctic climate system have likely had an impact on ice phenology of lakes in coastal regions adjacent to the Arctic Ocean.

Changes in lake ice cover could in turn have an important feedback effect on energy exchanges between the lake surface and the atmosphere, and on water levels and therefore on lake water balance, water properties and quality. As a result, water resources, food supply, aquatic habitat, and underlying permafrost conditions will undergo changes at various spatial and temporal extents. Through their heat and water budgets, lakes play an important role in the local and regional climate of high-latitude regions. Longer open-water seasons lead to increased exposure to solar radiation that, through evaporation, results in extended latent heat release from lakes to the atmosphere, the amount of latent heat being twice that released by the adjacent tundra (Mendez et al., 1998). In permafrost areas such as the North Slope of Alaska (NSA), changes in lake water balance, dynamics or temperature can also disturb the underlying permafrost layer, resulting in thaw (Romanovsky et al., 2010) with consequent talik formation and lateral lake water drainage, and also in carbon dioxide and methane release to the atmosphere (Walter et al., 2006). The presence of liquid water underneath ice extends fresh water availability for residential and industrial use throughout the winter. The changing ice cover of highlatitude lakes not only alters the physical and thermal properties of lakes but also affects the chemical properties and the dependent biota; warming lake water temperatures may lead to extinction, blooming or migration of various biological species. However, the magnitude to which changes within the Arctic lakes affect the dependent ecosystem is complex but yet poorly understood and remains to be further investigated.

In response to warmer climatic conditions and to changes in snow cover in recent decades, break-up dates in particular have been occurring earlier in many parts of the Northern Hemisphere (Magnuson et al., 2000; Duguay et al., 2006). The presence of trends in lake ice duration may be occasionally masked by the seasonal, annual or decadal variability that is influenced by the intensity and duration of a climatic episode. Under warmer climate conditions, shallow tundra lakes, many of which are less than $3 \mathrm{~m}$ deep, are expected to develop thinner ice covers, likely resulting in a smaller fraction of lakes that freeze to their bed in winter, earlier ice-off dates, and overall shorter ice seasons. Shallow lakes of the Alaskan Arctic Coastal Plain (ACP), Arctic Siberia (Grosswald et al., 1999; Smith et al., 2005; Sobiech and Dierking, 2012), the Hudson Bay Lowlands (Duguay et al., 1999, 2003;

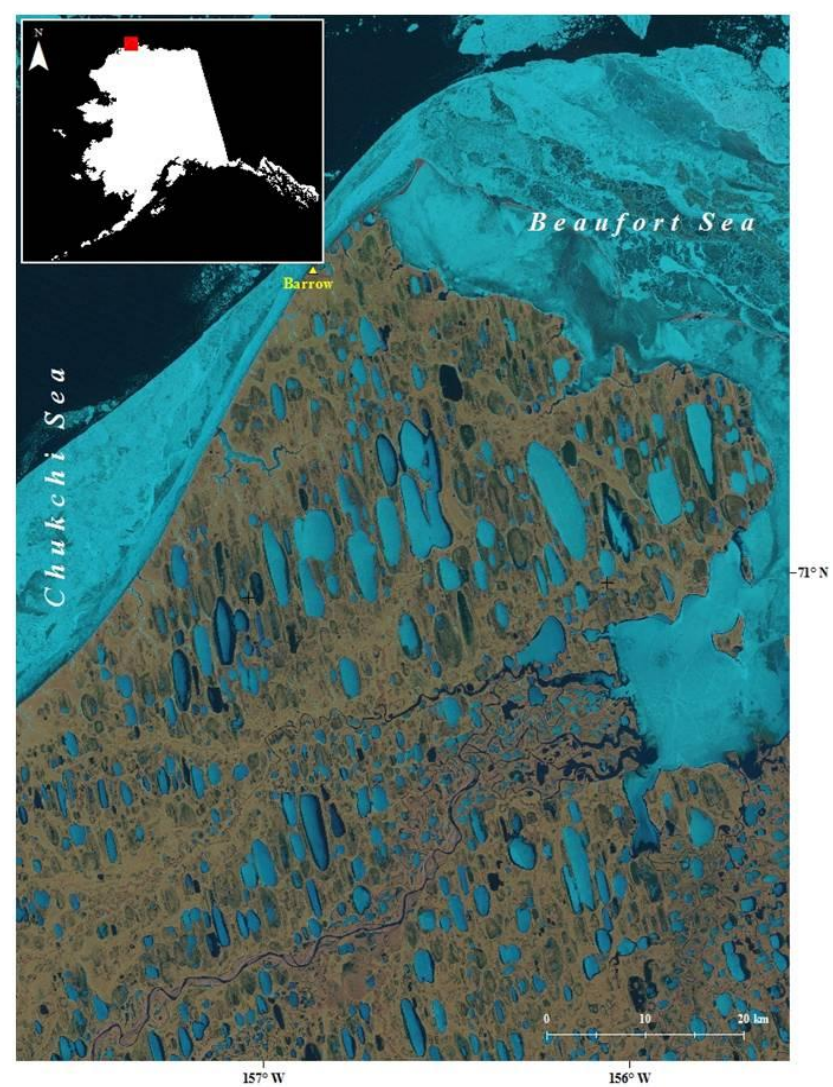

Fig. 1. Sub-region of the Alaskan Arctic Coastal Plain, near Barrow $\left(71^{\circ} 17^{\prime} \mathrm{N}, 156^{\circ} 46^{\prime} \mathrm{W}\right)$. The satellite view of Barrow was provided by NASA, Landsat program 2011, Landsat TM L1T scene (ID: LT50790102011170GLC00). Publisher: USGS. Acquisition date 9 June 2011.

Duguay and Lafleur, 2003; Brown and Duguay, 2011a) and other similar regions in the Arctic, have likely been experiencing changes in seasonal ice thickness and phenology (e.g., freeze-up, break-up, and ice cover duration) over the last decades but few studies have documented these changes.

Past changes in lake ice cover have mostly been identified only through non-spatially representative point in situ measurements, which have been almost unavailable over the last two decades following the decline of the global terrestrial monitoring network for fresh-water ice (Lenormand et al., 2002; Prowse et al., 2011). Recent studies have demonstrated that satellite remote sensing provides a viable alternative to detecting and monitoring changes of the ice cover on high-latitude lakes (Latifovic and Pouliot, 2007; Arp et al., 2012; Duguay et al., 2012). Previous remote-sensing investigations indicate that optical sensors are not the ideal tool for comprehensive monitoring of lakes since they are limited by the presence of cloud cover and extended polar darkness (Hinkel et al., 2012), and in most cases, by moderate spatial resolution (i.e., 100-1000 m). Instead, with fewer restrictions (i.e., allowing imaging under cloudy and darkness 


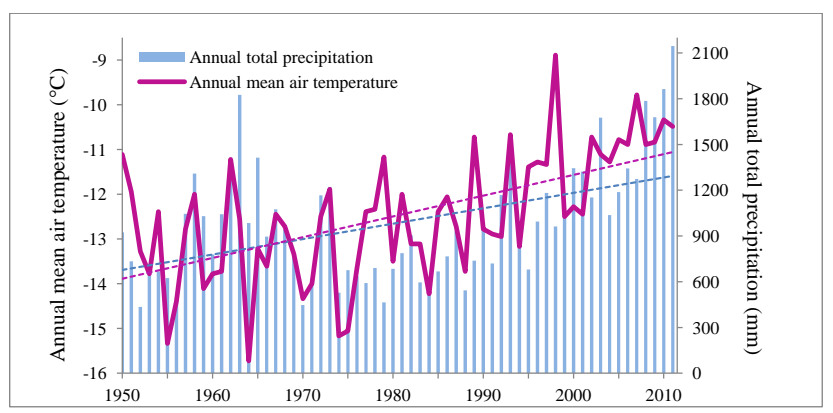

Fig. 2. 1950-2011 annual mean air temperature and total precipitation (rain and snowfall) as recorded at the National Weather Service station, Barrow, AK. The dashed lines indicate the trend for annual mean air temperature $\left(2.9^{\circ} \mathrm{C}\right.$ increase in $\left.62 \mathrm{yr}, \alpha=0.001\right)$ and for annual total precipitation $(639 \mathrm{~mm}$ increase in $62 \mathrm{yr}, \alpha=0.001)$.

conditions), spaceborne synthetic aperture radar (SAR) has been shown to be the most efficient tool for detecting changes in Arctic lake ice (Jeffries et al., 1994, 2005; Morris et al., 1995; Duguay et al., 2002; Cook and Bradley, 2010; Arp et al., 2012; Jones et al., 2013). Recent attempts to identify the response of shallow lakes of the NSA to contemporary climate conditions exist and changes in the grounded ice fraction has been noticed. However, the short period covered by these studies using satellite observations, 2003-2011 (Arp et al., 2012) and 2008-2011 (Engram et al., 2013) precludes identification of a trend.

The climate trajectory in the Barrow region has taken an abrupt turn during the first decade of the 21 st century, with mean air temperatures increasing by $1.7^{\circ} \mathrm{C}$ (Wendler et al., 2012), a change that has been shown to impact the lake ice regimes in this coastal region. Consequent to warmer air temperatures and increased precipitation (Callaghan et al., 2011) during recent decades (Fig. 2), the ice regimes of these shallow lakes are expected to develop thinner ice covers, earlier melt, and shorter ice seasons. Transition toward higher floating ice fractions, with more lakes maintaining liquid water underneath the ice cover and fewer lakes freezing to the bottom by the end of winter is also likely to occur.

The objectives of this study are to identify changes in the maximum ice thickness by Arctic shallow lakes as derived from both SAR satellite observations and numerical modeling scenarios during recent decades, to report observed and simulated changes in the ice phenology of these lakes from 1950 to 2011, and to determine potential ice regime trends during recent decades. To achieve these goals, this study (1) analyzes and reports monthly changes in the fraction of lakes that froze to the bed in winter between 1991 and 2011, (2) evaluates the rate of change of late winter maximum ice thickness during the past two decades, (3) presents the identified changes in lake ice thickness and duration as derived from a numerical lake ice model (1950-2011), and (4) cor- relates SAR-detected changes within the lake ice cover with model-simulation results (1991-2011).

\section{Background}

Airborne X-band and C-band SAR images acquired over shallow lake regions have been shown to be useful for determining the presence of floating or grounded ice (Weeks et al., 1978; Mellor, 1982) and timing of lakes that freeze to their bed in winter (Elachi et al., 1976). The first analysis of ERS-1 SAR data over lakes on the NSA was performed by Jeffries et al. (1994) during the ice season of 1991/1992. The study shows that monitoring the evolution of radar return, also referred to as radar backscatter intensity $\left(\sigma^{\circ}\right)$, is an efficient tool in detecting ice onset and melt, as well as floating or grounded ice. The low temporal resolution of the ERS sensors, a repeat cycle of 35 days, would not be suitable for the determination of freeze-up and break-up dates. However, considering that this study focuses on the determination of grounded and floating ice during the ice growth season, this is not a significant issue since high-temporal resolution is not necessary (i.e., ERS observations still allow for the monitoring of monthly changes in the fraction of floating and grounded ice, and appropriate comparison between years). In order to complement these observations and be able to simulate freeze-up and break-up dates with a daily temporal resolution, CLIMo was employed.

Similar work by Jeffries et al. (1996) used SAR coupled with a numerical lake ice model to determine the timing of maximum ice thickness and the number of lakes on the NSA that freeze to their bottom, and estimate the depth of these lakes. These results are summarized in the study area section of this paper. Likewise, Duguay et al. (1999) and Duguay and Lafleur (2003) evaluated the presence of floating and grounded lake ice, and the timing of maximum ice thickness, with ERS-1 SAR observations of the Hudson Bay Lowlands, near Churchill, Manitoba. Methods developed in these earlier investigations have been recently applied to map fish overwintering habitat in channels of the Sagavanirktok River, Alaska (Brown et al., 2010), to estimate methane sources (Walter et al., 2008) or to determine winter water availability in Alaska (White et al., 2008). Providing that discrimination between floating and grounded ice is facilitated by the high contrast displayed in SAR images, $\mathrm{C}$-band SAR has been shown to be the most useful frequency for distinguishing between the two different ice cover conditions (Engram et al., 2013).

Generally, low radar returns $(-17$ to $-12 \mathrm{~dB})$ in C-band ERS-1/2, VV polarized SAR imagery indicate the presence of a thin, relatively uniform ice cover at the beginning of the ice season, associated with specular reflection off the icewater interface (Duguay et al., 2002). Low radar backscatter also attests the existence of grounded ice later into the growing season, explained by the low dielectric contrast at the 
ice-lake-bottom interface and the absorption of the radar signal into the substrate (Jeffries et al., 1994). Steady increase in radar backscatter persists during the ice season, from November to April, as ice continues to grow and remains afloat. Maximum returns $(-11$ to $-2 \mathrm{~dB})$ are associated with the presence of floating ice. Higher backscatter from floating ice is a combination of high difference in dielectric properties between the ice and the underlying liquid water (Weeks et al., 1978), and the presence of air inclusions in the ice layer. The higher radar return could also be explained by the presence of smaller tubular bubbles formed during freeze-up or of larger ebullition spherical bubbles, resulting in a doublebounce effect (Mellor et al., 1982). Ice decay at the end of the season is characterized by low radar returns from the melting ice and snow, and/or ponding water that reflect the radar signal in a direction away from the sensor (Duguay et al., 2002).

\section{Study area}

The study focuses on a region that encompasses 402 lakes, near Barrow $\left(71^{\circ} 31^{\prime} \mathrm{N}, 156^{\circ} 45^{\prime} \mathrm{W}\right)$ on the NSA (Fig. 1), an area that is dominated by the ubiquitous presence of shallow thermokarst lakes, lakes that are reported to cover up to $40 \%$ of the coastal plain (Sellmann et al., 1975; Hinkel et al., 2005). The area is dominated by the polar marine climate, with cold air temperatures and high winds. The mean annual air temperature (1921-2011) recorded at Barrow is $-12^{\circ} \mathrm{C}$ and the mean annual precipitation fall is $845 \mathrm{~mm}$ (106 mm liquid precipitation and $739 \mathrm{~mm}$ snowfall). The east, east-northeast prevailing wind has a mean annual speed of $19.1 \mathrm{~km} \mathrm{~h}^{-1}$ (National Climate Data Center, 2012). Summer air temperatures are usually highest in July, with a mean air temperature of $4.4^{\circ} \mathrm{C}$, and lowest in February, with a mean of $-26.6^{\circ} \mathrm{C}$.

The area of lakes investigated in this study ranges from 0.1 to $58 \mathrm{~km}^{2}$. Despite the unknown bathymetry for the majority of these lakes, using a numerical ice-growth modeling approach, Jeffries et al. (1996) determined that $23 \%$ of the lakes may be deeper than $2.2 \mathrm{~m}, 10 \%$ with depths ranging from $1.5 \mathrm{~m}$ to $2.2 \mathrm{~m}, 60 \%$ between $1.4 \mathrm{~m}$ and $1.5 \mathrm{~m}$, and $7 \%$ less than $1.4 \mathrm{~m}$. A considerable number of lakes on the Alaskan ACP freeze to their bed each ice season (Mellor, 1982), and are ice free for only eight to ten weeks per year (Jeffries et al., 1996). Ice formation, mostly a function of lake morphometry and air temperature, commences in midSeptember (Jeffries et al., 1994; Liston et al., 2002; Jones et al., 2009) or early October (Hinkel et al., 2003) and attains a maximum growth rate in November (Jones et al., 2009) that is followed by a slower growth rate until early March or later (Jeffries et al., 1996), when many shallow lakes freeze to the bottom. Depending on lake water depth, the timing of maximum ice thickness varies and can occur any time between late April (Jeffries et al., 1996) and May (Jones et al., 2009). Changes in air temperature, snowfall timing and snow depth prior to and during all months of freeze-up (ice-on) and break-up (ice-off) affect the timing of these ice events. However, maximum ice thickness is primarily driven by changes in the April air temperature and it happens earlier by six days following higher air temperatures and is delayed by seven days if lower April air temperatures occur. Changes in April snow depth do not affect the timing of maximum ice thickness (Morris et al., 2005).

April air temperature (monthly mean of the $2 \mathrm{~m}$ air temperature) was shown to also strongly affect the ice decay of central Alaskan lakes, with a $\pm 1{ }^{\circ} \mathrm{C}$ change in air temperature resulting in an advance or delay of break-up dates by \pm 1.86 days (Jeffries and Morris, 2007). Ice break-up of lakes on the NSA is driven by changes in air temperatures and the presence of an insulating snow cover, and may commence as early as April and last until June (Hinkel et al., 2003) or even July (Hinkel et al., 2012), when lakes become completely ice free. Field measurements indicate that snow is still present on lakes during the month of April (Jeffries et al., 1994; Sturm and Liston, 2003) hence ice break-up commences after the disappearance of the snow cover on top of lakes in late April or May.

\section{Data and methods}

\subsection{SAR-image processing}

A time series of 79 SAR images from 1991 to 2011, between December and early May, standard low resolution $(100 \mathrm{~m}$ pixel size and $240 \mathrm{~m}$ spatial resolution) ERS-1/2 (C-band, $5.3 \mathrm{GHz}$ ), VV polarized (vertical transmit and vertical receive), ascending and descending passes, was radiometrically calibrated and geocoded with the MapReady software (v2.3.17) provided by the Alaska Satellite Facility (ASF). Following calibration and geocoding, each individual image was segmented in order to derive the ice cover fractions for both floating and grounded (bedfast) ice.

In order to ensure that the images used in the analysis were not affected by possible melt at the end of the ice season, daily air temperatures recorded at the Barrow meteorological station were also taken into consideration in order to confirm that air temperature values prior to and at the time of SAR acquisitions were below $0{ }^{\circ} \mathrm{C}$. Optimum radar images - not affected by possible melt at the end of the ice season - are acquired during April (Mellor, 1982), also coinciding with the approximate timing of maximum ice thickness in this study area. As SAR imagery was not consistently available on the same date during the $20 \mathrm{yr}$ of study, assessment of differences in the grounded ice fraction between images acquired a few weeks apart was also performed. April to early May imagery was selected to derive the fraction of lakes frozen to the bed since images acquired later in the season may be affected by the presence of wet snow or ponding water on the ice surface and therefore result in erroneous results (Hall et al., 
1994). Evaluation of differences between the ascending and descending pass acquisitions at a two-day interval showed a difference of $1.5 \%$ to $2 \%$ in the fraction of grounded ice. The higher fraction of grounded ice was consistently noticed in the descending pass images, acquired two days after the ascending pass. The differences in the grounded ice fraction observed in the overlapping ascending and descending images are attributed to the right-looking ERS geometry. The SAR looking geometry of ERS - from the east in ascending mode and from the west in descending mode - limits the identification of the exact same ground features in overlapping images due to the angle of illumination. Issues such as foreshortening and layover are known to result in possible deformations in area where the topographic slope is greater than $10^{\circ}$. Considering that the study area is a coastal plain, such deformations are likely minimum and the difference in the grounded ice fraction is associated with the illumination differences.

ERS imagery (December to March) was not available on a monthly basis during the $20 \mathrm{yr}$ period. However, SAR acquisitions during April were available for each year included in the study, except for 1996, 2002 and 2004 when images acquired on 3 May, 2 May, and 6 May were used to obtain the late-winter grounded ice fractions.

In order to map lake areas frozen to the bed and those with ice afloat in the Barrow region of the ACP, image segmentation was performed for the 79 ERS-1/2 acquisitions (Fig. 3 shows segmentation results of late winter images). The automated segmentation combines gradual increased edge penalty and region growing techniques, both incorporated in the Iterative Region Growing with Semantics (IRGS) algorithm and implemented in the MAp-Guided Ice Classification System (MAGIC) software (Clausi et al., 2010). The method, proved to be robust, has been fully validated and is being successfully used by Environment Canada's Canadian Ice Service (CIS) for sea-ice classification. The statistical and spatial characteristics of pixels in SAR images have been effectively modeled with IRGS and successfully used in a recent study to map and monitor ice cover on large northern lakes (Ochilov et al., 2010). Given that different ice types are present on lakes, a three-cluster segmentation (two floating ice classes and one grounded ice class) was used. In order to further verify the performance of the three-cluster segmentation, a five-cluster segmentation was at times performed. Following the input of each individual SAR image and the corresponding vector file of lakes included in the study area, automated image segmentation is performed with IRGS, and the output is a file that includes fractions for all three classes that were initially selected by the operator. In order to determine the total fraction of grounded and floating ice, visual assessment of each segmentation result against the original SAR image is performed, and all resulting ice classes are merged into two classes (grounded and floating ice) by a human operator. Once merging was completed, a two-class map was generated for each date of SAR imagery included in the analysis. Low-resolution (100 m pixels) images were segmented with IRGS and further classified as floating and grounded ice. The current study extends the use of IRGS in documenting and analyzing changes in ice cover on shallow lakes.

\subsection{Lake-ice modeling}

The lake ice model CLIMo was used to derive lake ice thickness, freeze-up and break-up dates. CLIMo was forced using data obtained from the online archives of the National Climate Data Center (mean daily $2 \mathrm{~m}$ screen air temperature, relative humidity, wind speed, cloud cover fraction, snow depth) for the Barrow meteorological station (19502011). As meteorological data was not available for all years prior to 1950 , the model was forced with available data from 1950 onward. In order to capture the typical observed variability in snow depth on Arctic coastal lakes, simulations were performed with two scenarios: one that assumed that no snow was present on the ice surface $(0 \%)$ and a second one that assumed a $53 \%$ snow cover depth, calculated as a fraction from the total snow depth measured over land. The mean lake depth specified in the lake model simulations was $3 \mathrm{~m}$. This model has been extensively tested over various lake regions, including the NSA (Duguay et al., 2003). CLIMo results presented in the study were in good agreement with both ERS-1 SAR observations and in situ measurements during the winter of 1991-1992. For example, the simulated ice-on date was 19 September, while satellite observations indicated that freeze-up occurred between 11-20 September 1991 (Jeffries et al., 1994). Similarly, the latest ice-off date simulated with CLIMo in a no-snow scenario was 14 July 1992 and the SAR-derived one was 15 July 1992 (Zhang and Jeffries, 2000), only one day apart. Maximum ice thickness simulations $(165-221 \mathrm{~cm})$ in snow depth scenarios ranging from zero to $100 \%$ displayed differences of 5-6 cm when compared to field measurements (159$216 \mathrm{~cm}$ ) during 19-29 April (Jeffries et al., 1994). More recently, the model has been further evaluated for a shallow lake near Churchill, Manitoba (Brown and Duguay, 2011a), and at the pan-Arctic scale for lakes of various depths (Brown and Duguay, 2011b). Analysis of model performance at the pan-Arctic scale showed that the average absolute error for determining ice-on and ice-off dates was less than one week when compared to field observations on 15 lakes in northern Canada. The mean maximum ice thickness difference between simulations and in situ measurements for three sites was $12 \mathrm{~cm}(6.5 \%)$.

Wind redistributes snow, resulting in a thinner and denser snow layer over lakes than over land (Sturm and Liston, 2003 ), with a reported average fraction of $52 \%$ between the snow depth measured over lake ice and the snow depth measured over land at the Barrow weather station (Zhang and Jeffries, 2000). Considering the wide fluctuations in snow cover fraction associated with its redistribution during the 

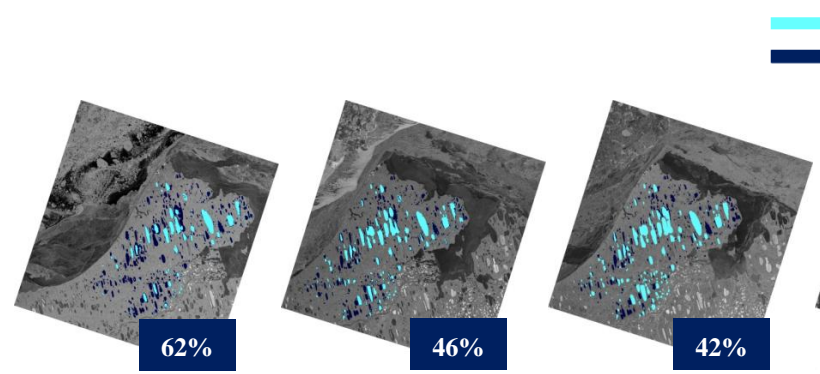

Floating ice

20 April 1992

21 April 1993

29 April 1994

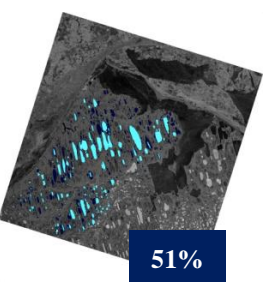

14 April 1995
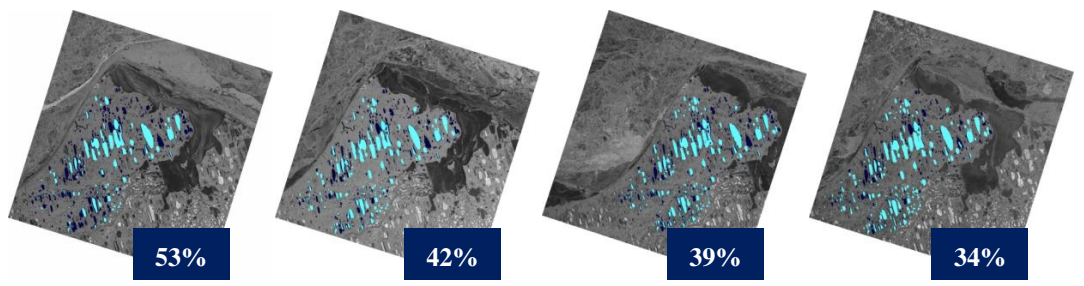

3 May 1996

19 April 1997

23 April 1998

24 April 1999
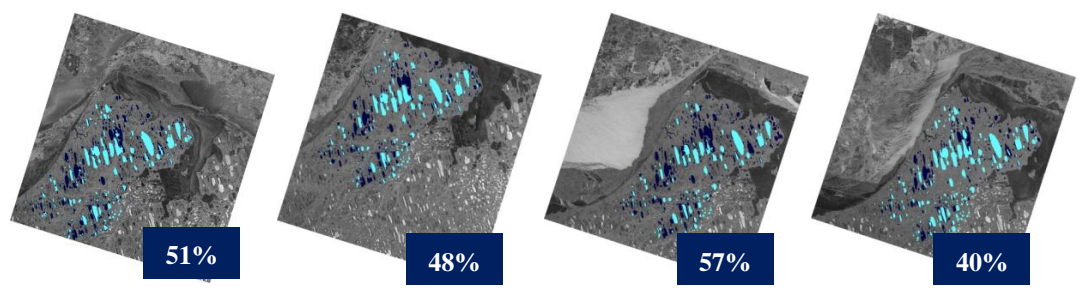

22 April 2000

28 April 2001

2 May 2002

17 April 2003
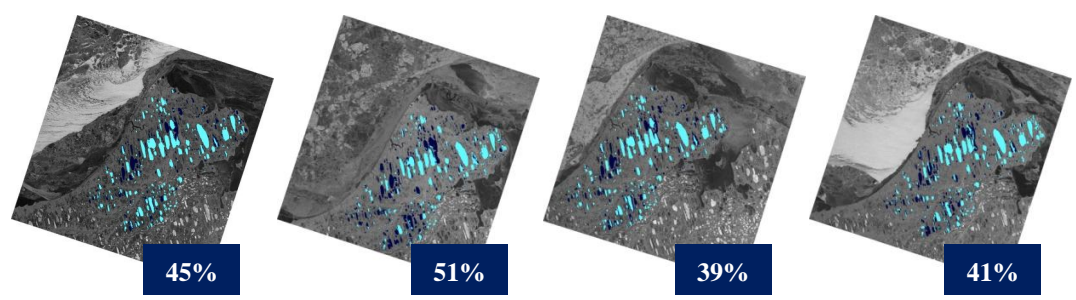

17 April 2004

21 April 2005

22 April 2006

26 April 2007
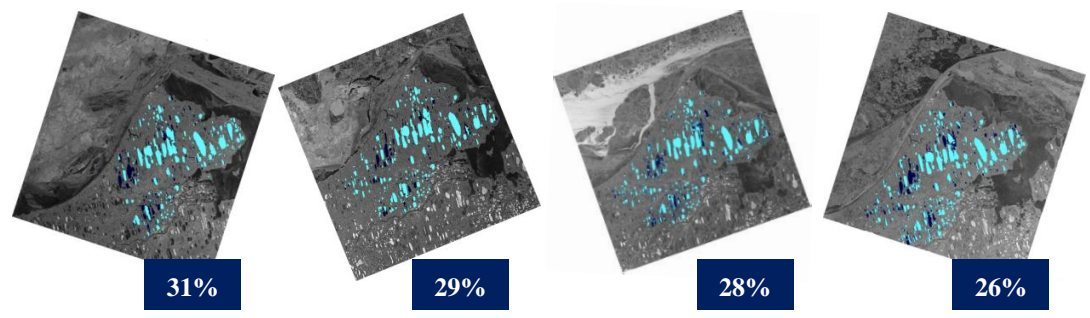

5 April 2008

25 April 2009

29 April 2010

16 April 2011

Fig. 3. Image segmentation results of ERS-1/2 SAR images acquired near the time of maximum ice thickness for lakes near Barrow, from 1992 to 2011. The fraction of grounded ice for each date is also shown. Data source: Alaska Satellite Facility. All SAR images are copyright ESA (1992-2011). 
Table 1. Dates of ERS-1/2 acquisitions used for image segmentation in order to determine the monthly fraction of grounded ice (1991-2011).

\begin{tabular}{|c|c|c|c|c|c|c|}
\hline \multirow[b]{2}{*}{ Year } & \multicolumn{6}{|c|}{ Day and month of SAR acquisition } \\
\hline & Dec & Jan & $\mathrm{Feb}$ & Mar & Apr & May \\
\hline 1991 & 30 & & & & & \\
\hline 1992 & 16 & 20 & 13 & 17 & 20 & \\
\hline 1993 & 25 & 25 & 10 & 17 & 21 & \\
\hline 1994 & 10 & 21 & 17 & 16 & 29 & \\
\hline 1995 & 15 & 16 & 22 & 11 & 14 & \\
\hline 1996 & & 04 & 23 & & & 3 \\
\hline 1997 & 20 & & 8 & & 19 & \\
\hline 1998 & 24 & 24 & 12 & 19 & 23 & \\
\hline 1999 & & 28 & & & 24 & \\
\hline 2000 & 28 & 13 & 17 & 23 & 8 & \\
\hline 2001 & 13 & & & 24 & 28 & \\
\hline 2002 & & 17 & & & & 2 \\
\hline 2003 & 18 & & 6 & & 17 & \\
\hline 2004 & 18 & 17 & 21 & 11 & & 6 \\
\hline 2005 & 22 & 22 & 10 & 17 & 21 & \\
\hline 2006 & & & & 16 & 22 & \\
\hline 2007 & 22 & & & 22 & 26 & \\
\hline 2008 & 27 & 12 & & 22 & 10 & \\
\hline 2009 & 31 & 15 & 19 & 26 & 9 & \\
\hline 2010 & & 16 & 20 & 25 & 29 & \\
\hline 2011 & & 20 & & 17,26 & 16 & \\
\hline
\end{tabular}

winter season and accounting for wide variations observed in snow density $\left(198-390 \mathrm{~kg} \mathrm{~m}^{-3}\right)$ in this area (Sturm and Liston, 2003), model simulations for the snow scenario were performed with a $53 \%$ snow depth fraction and a fixed snow density of $335 \mathrm{~kg} \mathrm{~m}^{-3}$. The calculated snow depth fraction over lakes and model input for snow density was based on available field measurements in the Barrow region from 1991 to 2006 .

\section{Results}

\subsection{SAR-data analysis}

A $20 \mathrm{yr}$ time series of ERS-1/2 SAR images (1991-2011), with acquisition dates between mid-December and early May, was analyzed (Table 1). The results show not only an expected inter-annual variability but also a gradual transition toward higher floating ice fractions, particularly noticed during recent years. The observed fraction of grounded ice, calculated as a monthly mean, gradually increased during the winter, from a December mean of $15 \%$ to a mean of $43 \%$ in April, when ice is most likely to grow to its maximum thickness. Assessment of grounded ice fractions during the winter seasons (1991-2011) with available ERS imagery indicates a gradual trend toward lower fractions of grounded ice in all months of observations in the image time series. The greatest change was observed to occur in April, with maximum deviation values $( \pm 15-18 \%)$ from the monthly mean of $43 \%$ calculated from all years (1992-2011) and a standard deviation of 9.83 . The highest positive deviation was observed in 1992 (more grounded ice) and the highest negative value in 2011 (less grounded ice). The transition toward lower fraction of grounded ice during late winter (April) correlates well with the trend toward thinner ice covers as indicated by model simulations during the same period $(r=0.75$, $p<0.001$; Fig. 4).

The trend accentuated from 2006 onward (as observed in Fig. 5), observation also reported in a similar study from an adjacent region of the NSA (Arp et al., 2012). Trend detection was performed using the Mann-Kendall test, a method often used for detecting the presence of linear trends in long-term lake ice observations (Futter, 2003; Duguay et al., 2006). Trend magnitude (slope) was estimated with Sen's method (Sen, 1968; Duguay et al., 2006; Noguchi et $\mathrm{al}, 2011)$. Statistical analysis of SAR data over the $20 \mathrm{yr}$ period, indicates a decrease of $22 \%$ in the fraction of lakes that freeze to the bed in April $\left(1.1 \% \mathrm{yr}^{-1}, \alpha=0.01\right)$. The maximum number of lakes froze to their beds in 1992 when the fraction of grounded ice was $62 \%$, as opposed to 2011 when a minimum fraction of $26 \%$ of bedfast ice was noticed. The 2011 lowest April fraction of grounded ice was also observed with Envisat Advanced Synthetic Aperture Radar (ASAR) imagery from 2003 to 2011 (Arp et al., 2012).

\subsection{Model results}

The performance of CLIMo vs. field-measured ice-on, iceoff dates, and thickness and against ice-on and ice-off dates from satellite observations was previously shown to agree well (Duguay et al., 2003). To further demonstrate the good agreement of CLIMo with in situ measurements, model results were statistically compared to observed mean ice thickness during several years with available field data. Accurate ice thickness simulations are dependent on using representative snow cover depths and densities over lakes for model runs. Data on ice thickness, snow cover depth, and (rarely) snow density over lakes is available for a selection of lakes near Barrow for the 1978/79 (Imikpuk Lake, Ikroavik Lake and West Twin Lake; Mellor, 1982) and 1991/1992 (Ikroavik Lake, Emaiksoun Lake and Emikpuk Lake; Jeffries et al., 1994) ice seasons. The mean bias error (MBE) with both snow scenarios $(0 \%$ and $53 \%)$ compared to in situ measurements was $+8 \mathrm{~cm}(4 \%)$, indicating that CLIMo generates reliable ice thickness simulations for lakes in the Barrow region.

The longer historical-trend analysis (1950-2011) of maximum ice thickness derived from CLIMo simulations indicates the development of thinner ice covers on the Alaskan shallow lakes. Model runs with two different snow scenarios ( $0 \%$ and $53 \%$ snow cover depth), forced with data from the Barrow meteorological station, show a significant 

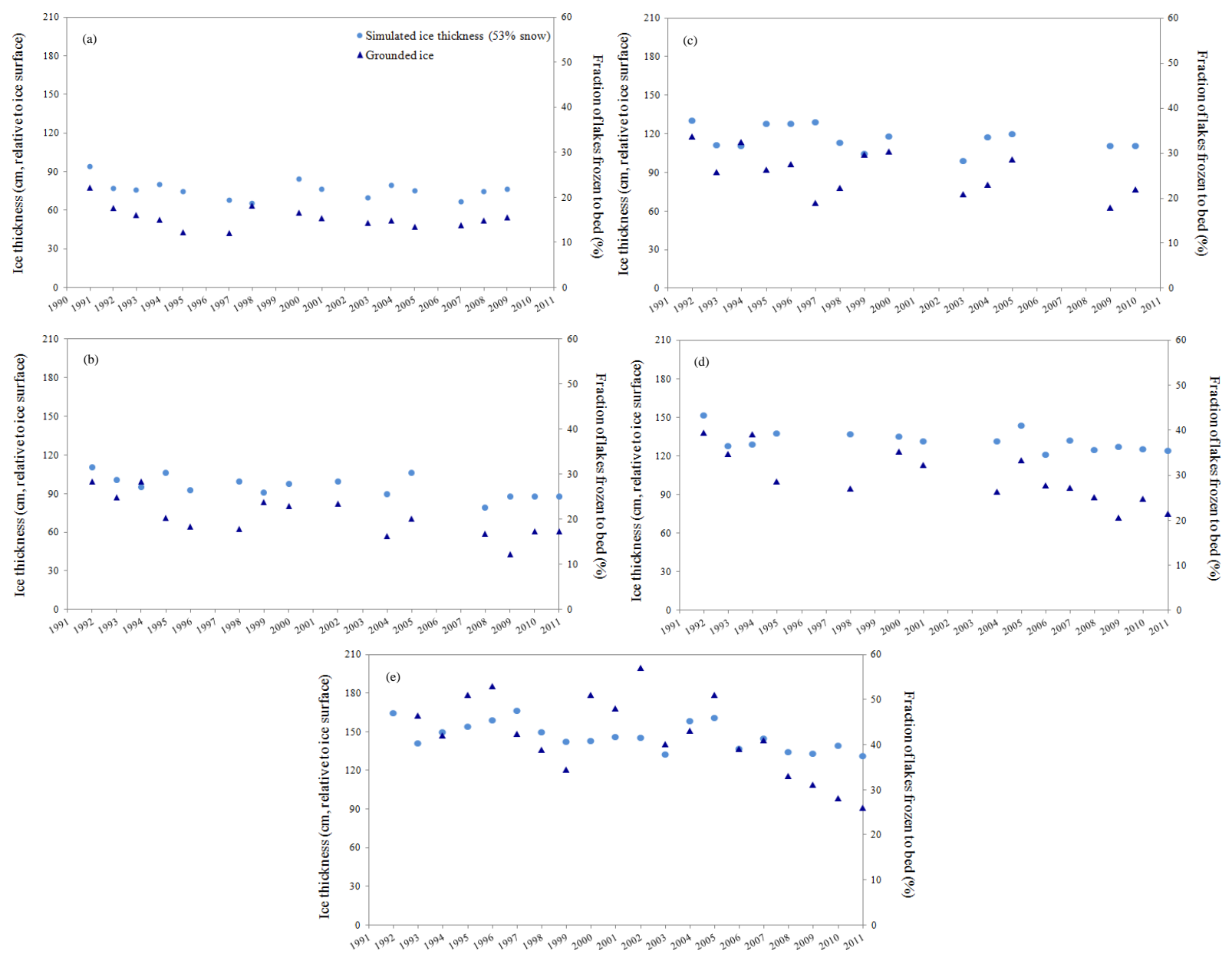

Fig. 4. Monthly fractions of lakes frozen to bed as derived from analysis of available ERS images and simulated ice thickness on day of ERS acquisition (1991 to 2011) - (a) December; (b) January; (c) February; (d) March; (e) April.

decline $(\alpha=0.001)$ in the maximum ice thickness of a total of $21 \mathrm{~cm}$ (no-snow cover) and $38 \mathrm{~cm}(53 \%$ snow cover depth) for the period 1950-2011. Simulated maximum ice thickness with $0 \%$ and $53 \%$ snow cover depth, respectively, ranged from $196 \mathrm{~cm}$ and $140 \mathrm{~cm}$ in 2011 to $238 \mathrm{~cm}$ and $209 \mathrm{~cm}(\alpha=0.001)$ in 1976. The ice thickness simulated with CLIMo using a snow depth of $53 \%$ correlates well with the SAR-derived ice cover fractions for lakes frozen to the bed vs. lakes with floating ice $(r=0.75, p<0.001)$, a thinner ice cover corresponding to a lower fraction of lakes frozen to the bed and thicker ice indicating a higher grounded ice fraction (Fig. 6). For the overlapping years with the ERS-1/2 SAR images (1991-2011), model simulations with no-snow and $53 \%$ snow depth scenarios show a decline in the maximum ice thickness by $18-22 \mathrm{~cm}(\alpha=0.01)$.

Additionally, CLIMo simulations indicate that, in response to warmer climatic conditions as reflected by the increase in annual mean air temperature and total precipitation during recent decades, the duration of the ice cover has reduced, with later freeze-up dates by 5.9 days and break-up dates occurring earlier in the season by 18.6 days with $0 \%$ snow cover and by 17.7 days with the $53 \%$ snow cover depth scenario from 1950 to 2011 (Fig. 7). During the $62 \mathrm{yr}$ period, CLIMo indicates a decrease in the duration of the ice seasons by a total of 24.8 days in the absence of a snow cover and by 23.6 days with $53 \%$ snow cover depth. Statistically, freeze-up and break-up, and the duration of the ice season trends, with both snow cover depth scenarios, are equally significant at the $\alpha=0.001$ level. For the period of the ERS imagery analysis (1991-2011), model simulations indicate later ice-on dates by 14.5 days ( $\alpha=0.05)$, earlier ice-off dates by 5.3 days $(\alpha>0.1)$ with the no-snow scenario and no change in the ice-off dates $(\alpha>0.1)$ with the $53 \%$ snow depth scenario. 


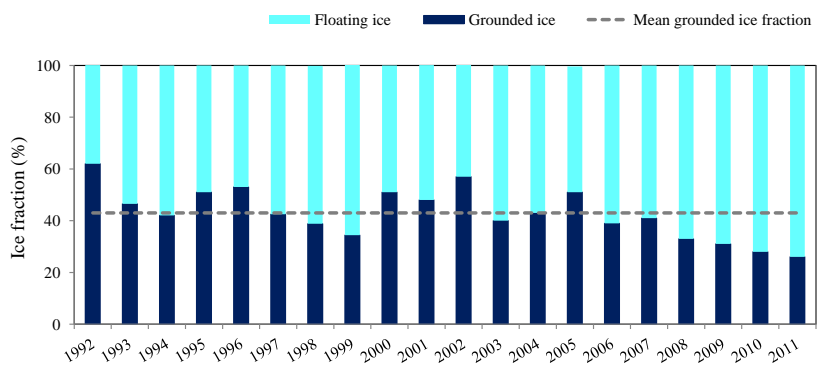

Fig. 5. Late winter (April/May) floating and grounded ice fractions from 1992 to 2011 resulting from segmentation of ERS-1/2 images.

\section{Discussion}

\subsection{Ice cover changes: 1950-2011}

Analysis of ice-thickness trends from CLIMo simulations during the 1950-2011 period indicates a trend toward thinner ice covers for the Alaskan lakes under study, a trend that is more evident with $53 \%$ snow cover depth conditions and that indicates a decrease of a total of $38 \mathrm{~cm}$ in ice thickness, at a rate of $0.6 \mathrm{~cm} \mathrm{yr}^{-1}$.

Albeit inter-decadal and inter-annual variability is noted, trend analysis of ice phenology from 1950 to 2011 indicates a slight change in freeze-up dates, ice onset occurring later in the season by 5.9 days and a significant advancement of ice melt by 17.7 to 18.6 days (0\% and $53 \%$ snow depth scenarios). These results are supported by similar findings that show a significant trend toward later ice-on and earlier ice-off dates, and overall shorter ice seasons of lakes across the Northern Hemisphere, a trend accentuated during recent decades (Magnuson et al., 2000; Duguay et al., 2006; Benson et al., 2011). Shorter ice seasons have been mainly attributed to the advance of break-up days earlier in the spring (Bonsal et al., 2006), earlier ice-off being associated with higher spring air temperatures and earlier snow melt onset (Duguay et al., 2006). CLIMo simulations for the 1950-2011 period suggest that the length of the ice season has reduced by 23.6-24.8 days (53\% and $0 \%$ snow cover depth scenarios). In a $53 \%$ snow cover depth scenario, the shortest ice seasons were identified to have been occurring in recent years, with 1998 being the year when lakes were ice free for a total of 101 days, followed by 2006 (ice free for 98 days) and 2009 (ice free for 97 days). Using the same climate scenario (53\% snow depth), model simulations show that 1955, 1960 and 1965 (51, 52, and 59 days respectively) were the years when lakes had the most extended ice coverage. To support the strong correlation previously shown to exist between iceoff dates and ice cover duration (Duguay et al., 2006), shorter ice seasons occurred in all years of early ice-off dates in both snow cover depth scenarios but not all years with reduced ice duration had later ice-on dates.

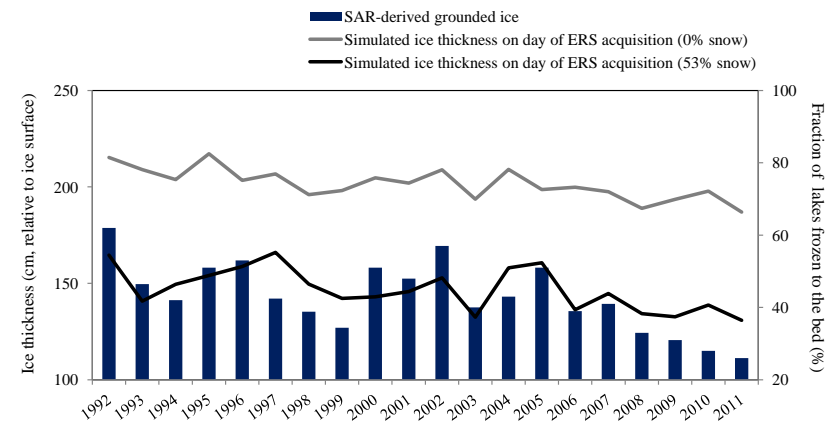

Fig. 6. SAR-derived fraction of grounded ice and simulated ice thickness from CLIMo on day of ERS acquisitions from 1992 to 2011.

\subsection{Ice cover changes: 1991-2011}

\subsubsection{SAR-observed changes}

During the $20 \mathrm{yr}$ period of SAR analysis, a specific temporal pattern in the evolution of the grounded ice fraction for individual lakes on a yearly basis was not observed. Considering that the fraction of grounded ice is strongly dependent on climate conditions, the inter-annual variability of air temperatures and that of the snow cover impacts is being reflected by the variations in the yearly bedfast ice fraction. For example, the climatic conditions of a cold winter (1991/1992) and a warm winter (2010/2011) season, differed largely. The icegrowing season (October to April) of 1991/1992 was characterized by lower mean air temperatures $\left(-22^{\circ} \mathrm{C}\right)$ and reduced total snowfall $(561 \mathrm{~mm})$ as opposed to the higher winter mean air temperatures $\left(-17.7^{\circ} \mathrm{C}\right)$ and greater amount of total snowfall $(1199 \mathrm{~mm})$ of 2010/2011. The observed fraction of lakes frozen to the bed was greater during the colder ice season, with values ranging from a minimum of $18 \%$ in December to a maximum of $62 \%$ in April. Noteworthy is also the fact that the fraction of grounded ice observed in April 1992 (62\%) was the highest among all years of available SAR data. In addition to inter-annual variability of the grounded ice fraction, inter-lake differences were observed during the $20 \mathrm{yr}$ of available SAR data. For instance, the shallower West Twin Lake $\left(71^{\circ} 16^{\prime} \mathrm{N}, 156^{\circ} 29^{\prime} \mathrm{W} ; 1.2 \mathrm{~m}\right.$ maximum depth), located close to the Beaufort Sea, developed bedfast ice during all years of observations, whereas the deeper Ikroavik Lake $\left(71^{\circ} 13^{\prime} \mathrm{N}, 156^{\circ} 37^{\prime} \mathrm{W} ; 2.1 \mathrm{~m}\right.$ maximum depth), further from the Arctic coast, maintained a floating ice cover throughout all winter seasons.

Ice regimes of shallow coastal lakes on the NSA correlate with the distance from the coast, with lakes closer to the coast in this study area preserving their ice cover later into the season (Hinkel et al., 2012). The discrepancies in ice regimes of these lakes may therefore be attributed to temperature gradients or snow-cover redistribution within the area and that are associated with the distance from the coast. Ice regimes 


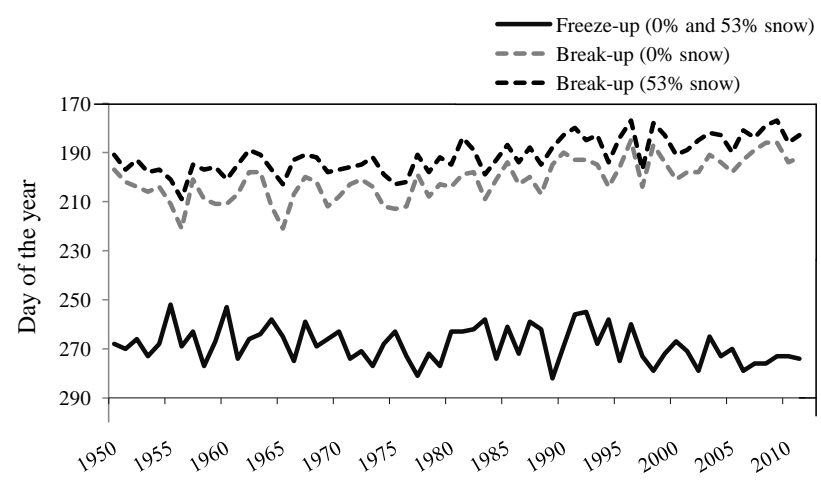

Fig. 7. CLIMo-simulated freeze-up and break-up dates from 1950 to 2011 .

are also related to lake depth, with deeper lakes maintaining liquid water underneath the ice (Jeffries et al., 1996).

\subsubsection{Simulated changes}

Ice growth and downward thickening is strongly influenced by snow cover over lake ice (Vavrus et al., 1996; Ménard et al., 2002; Gao and Stefan, 2004), which influences the vertical conductive heat flow from the ice to the atmosphere through heat loss at the ice-snow interface (Jeffries et al., 1999). A thinner and denser snowpack provides less insulation and allows higher rates of heat flow to the atmosphere (Sturm and Liston, 2003). Thus, the accentuated reduction of ice thickness and number of lakes that freeze to the bottom from 2006 onwards may be associated with deeper snow resulting from increased winter precipitation (Callaghan et al., 2011), a consequence of higher air temperatures (Schindler and Smol, 2006; Kaufman et al., 2009; Walsh et al., 2011). From 1991 to 2011, simulated ice thickness declined by 18 $22 \mathrm{~cm}$ (no-snow and $53 \%$ snow depth scenarios). Consequently, thinner ice covers are linked to the noticeable trend toward fewer lakes freezing to the bed during the past $20 \mathrm{yr}$, as observed from the analysis of SAR data (Fig. 6). Since ice cover conditions are better captured assuming a $53 \%$ snow depth atop lakes vs. no-snow cover when compared to available field measurements, analysis of overlapping CLIMo and SAR results indicate a closer agreement between the ice thickness and the fraction of grounded ice during the former scenario, with slight discrepancies in 1994, 1997, 2001 and 2010. The disagreement between model simulations and SAR observations is possibly associated with the timing of snow accumulation during the winter season, greater snow depth at the time of ice formation leading to thinner ice.

From 2006 onwards, model simulations indicate smaller changes in ice thickness whereas satellite observations indicate a significant reduction of the grounded ice fraction. One hypothesis to consider when explaining the considerable SAR-derived changes in grounded ice and the small changes in simulated ice thickness from 2006 onwards is the yearly variation in ice thickness. Minimum changes in ice thickness should occur, once a threshold is reached, thinner ice covers are reflected by the higher fractions of floating ice. Increasing lake water levels at the time of freeze-up or greater lake depths are aspects to also consider in explaining the differences between the changes in grounded ice and those in ice thickness. Since calculated precipitation $(P)$ minus evaporation $(E)(P-E)$ values do not indicate higher water levels from 2006 to 2011, changes in lake depth may explain the minor ice thickness changes. However, considering the lack of data on lake bathymetry, this hypothesis needs to be further investigated.

\subsection{Teleconnections and lake ice regimes}

Air temperature changes at high latitudes are often related to the decreasing extent of sea ice and that allows more heat to be absorbed by the Arctic Ocean, heat that is further released in the atmosphere. Additionally, changes in the air temperature are also associated with large-scale atmospheric and oceanic circulations. Previous analysis of teleconnection patterns that affect the Northern Hemisphere climate and weather reveals that lake ice conditions are partly driven by these large-scale circulations and exhibit stronger correlations with spring (January-April) climatic indices (Bonsal et al., 2006). For western Canada, the strongest correlation between teleconnections and ice phenology was associated with the Pacific-North American (PNA), a positive phase of the PNA being highly correlated with earlier breakup dates $(r=-0.74)$ and vice versa (Bonsal et. al., 2006). To articulate this relationship, one third of the variability in Northern Hemisphere winter temperatures variability of previous decades can be explained by the positive phase of the North Atlantic Oscillation (NAO; Hurell, 1996). Likewise, a shift of the Pacific Decadal Oscillation (PDO) in 1976 toward a positive phase contributed to increased northward advection of warm air (Morris et al., 2005), which is highly noticeable in Alaska, being well reflected by the recent increased warming of the area (Hartmann and Wendler, 2005). The PDO shift is also reflected in the CLIMo simulations that indicate a transition toward thinner ice covers from 1976 onward. Given that El Niño years have been associated with up to ten days shorter ice seasons for lakes in western Canada (Bonsal et al., 2006), the fact that the longest open-water season occurred during an extreme El Niño year (1998) is associated with considerable warmer air temperatures recorded that year at the Barrow meteorological station.

\subsection{Water levels and lake ice regimes}

In response to warmer climate conditions during recent decades, the spatial distribution and the surface area of Arctic lakes has been noted to change. In ice-rich permafrost areas such as the NSA, changes in air temperature alter the frozen ground layer that, by thawing, may result in the appearance 
of new water bodies or increasing surface areas of the existing lakes as a result of thermally induced lateral expansion (Jones et al., 2011). Alternatively, as many lakes in this area have low water volumes, lake water levels will rapidly respond to changes in the water budget, expressed as total precipitation $(P)$ minus evaporation $(E), P-E$. Calculated water balance during the ice-free season also includes spring snow-water equivalent (SWE). Thus, a negative water balance $(P<E)$ results in reduced lake levels and/or intermittent lake disappearance (Smol and Douglas, 2007) with lakes disappearing during dry seasons and refilling during wetter seasons. Hinkel et al. (2007) showed that from 1975 to 2000, over $25 \%$ of lakes on the western ACP experienced shoreline retreat through lateral drainage, the lake area change not being strongly supported by climate conditions during the period of analysis. This may be seen in the case of Sikulik Lake $\left(71^{\circ} 18^{\prime} \mathrm{N}, 156^{\circ} 40^{\prime} \mathrm{W}\right)$ that appears to have experienced fluctuating water levels during the $20 \mathrm{yr}$ period as indicated by the differences in radar returns from this lake in late winter (Fig. 8). As radar returns for this lake were similar to those of the adjacent land, the assumption made was that the lake drained in most years and that it may have filled in 2000 and 2002, both years with a positive water balance. Lake water levels are greatly controlled by precipitation and evaporation rates during the summer season when lakes are exposed to energy exchanges with the atmosphere and variations in the lake water balance can be explained by fluctuations in the $P-E$ (Bowling et al., 2003). In the case of Arctic lakes, the overall lake water balance is generally negative, as the high evaporation during summer is not compensated by higher amounts of precipitation (Rovansek et al., 1996). Positive values of the $P-E$ index are associated with lower annual mean air temperatures and wetter conditions during the ice-free season while lower water levels are recorded during warm and dry years (Labrecque et al., 2009). Extreme $P-E$ values (i.e., 1993, 2010, 2011 - warm years, and 1995, 2005 - cold years) correlate well with the grounded ice fraction, lower grounded ice fraction being strongly related to the positive $P-E$ values, and higher grounded ice values matching well those of negative $P-E$. During the years of extreme $P-E$ values, grounded ice fractions also correlate with mean air temperatures $(r=0.68, p<0.0010)$. Additional periodic recharge through ground water, spring snowmelt and river inflows, or lateral drainage and ice melt within the underlying permafrost (Young and Woo, 2000) can occur and consequently affect lake water balance, and thus explaining the discrepancies between lake water levels and ice conditions. These are tentative explanations and the relationship between water balance and grounded ice fraction needs to be further investigated. (a)

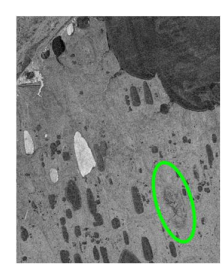

(b)

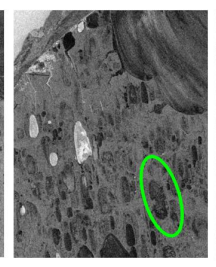

(c)

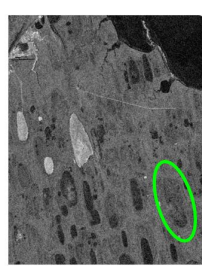

(d)

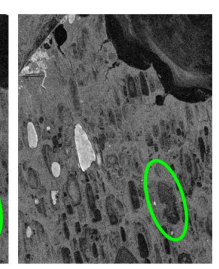

Fig. 8. Late winter (April/May) differences in radar returns from Sikulik Lake - (a) 1992; (b) 2000; (c) 2001; (d) 2002.

\section{Summary and conclusions}

This study aimed to detect changes in ice thickness, the fraction of lakes/lake areas freezing to the bed vs. those developing a floating ice cover and phenology (freeze-up and breakup dates, and ice cover duration) of Arctic shallow lakes near Barrow, in a sub-region of the NSA. The methods employed were image segmentation of ERS-SAR images acquired over the region from 1991 to 2011 and simulations with two different snow depth scenarios $(0 \%$ and $53 \%)$ of a numerical lake model forced with climate data from the Barrow meteorological station between 1950-2011.

A trend toward an increasing number of lakes that maintain liquid water underneath the floating ice atop in all months of available SAR imagery (December to early May), and thinner ice covers during the winter months was identified from ERS analysis and CLIMo simulations. Statistical analysis showed that in the case of thermokarst lakes near Barrow, the fraction of bedfast ice as extracted from the analysis of ERS-1/2 SAR data (1991-2011) correlates well with the thickness of the ice layer simulated with CLIMo. The most significant decrease in grounded ice was noticed to occur in late winter; grounded ice that considerably declined since 2006 and reached its lowest in 2011. Model outputs indicate thinner ice covers by 18 to $22 \mathrm{~cm}$ (1991-2011) and by 21 to $38 \mathrm{~cm}$ (1950-2011), and extended duration of the ice season - a function of later ice-on and earlier ice-off dates by a total of 23.6 days (1950-2011) with a $53 \%$ snow depth scenario.

SAR data provides the opportunity to effectively monitor Arctic lakes and assess the degree of changes in winter lake ice growth in response to climate conditions. Low-resolution ERS imagery allows an adequate detection of the rate at which lakes freeze to their bed for the duration of the ice season and of the grounded ice fraction at the end of winter, thus providing a valuable data set. The use of satellite sensors that provide higher temporal coverage, such as ASAR Wide Swath (2002-2012), would further improve the investigation of ice regimes of high-latitude lakes. Future satellite missions of the European Space Agency (Sentinel-1), the National Aeronautics and Space Administration (Surface Water and Ocean Topography - SWOT) and the Canadian Space Agency (the RADARSAT constellation) are planned 
for launch in 2013, 2019 and 2018, respectively. These missions will not only continue the C-band SAR operational applications (Sentinel-1 and the RADARSAT constellation) and enable accurate monitoring of water levels (SWOT) but also provide increased temporal resolution, thus ensuring frequent, long-term SAR acquisitions for the Arctic regions.

Acknowledgements. This research was supported by European Space Agency (ESA-ESRIN) contract no. 4000101296/10/I-LG (Support to Science Element, North Hydrology Project) and a Discovery Grant from the Natural Sciences and Engineering Research Council of Canada (NSERC) to C. Duguay. The ERS-1/2 SAR images are copyright ESA 1991-2011 and were provided by the Alaska Satellite Facility (ASF).

Edited by: D. Hall

\section{References}

Arp, C. D., Jones, B. M., Lu, Z., and Whitman, M. S.: Shifting balance of thermokarst lake ice regimes across the Arctic Coastal Plain of northern Alaska, Geophys. Res. Lett., 39, L16503, doi:10.1029/2012GL052518, 2012.

Assel, R. A., Cronk, K., and Norton, D.: Recent trends in Laurentian Great Lakes ice cover, Clim. Change, 57, 185-204, 2003.

Benson, B. J., Magnuson, J. J., Jensen, O. P., Card, V. M., Hodgkins, G., Korhonen, J., and Granin, N. G.: Extreme events, trends, and variability in Northern Hemisphere lake-ice phenology (18552005), Clim. Change, 12, 1-25, 2011.

Bonsal, B. R., Prowse, T. D., Duguay, C. R., and Lacroix, M. P.: Impacts of large-scale teleconnections on freshwater-ice break/freeze-up dates over Canada, J. Hydrol., 330, 340-353, 2006.

Bowling, L. C., Kane, D. L., Gieck, R. E., Hinzman, L. D., and Lettenmaier, D. P.: The role of surface storage in a low-gradient Arctic watershed, Water Resour. Res., 39, 1087, doi:10.1029/2002WR001466, 2003.

Brown, L. C. and Duguay, C. R.: A comparison of simulated and measured lake ice thickness using a shallow water ice profiler, Hydrol. Process., 25, 2932-2941, 2011 a.

Brown, L. C. and Duguay, C. R.: The fate of lake ice in the North American Arctic, The Cryosphere, 5, 869-892, doi:10.5194/tc5-869-2011, 2011b.

Brown, R. S., Duguay, C. R., Mueller, R. P., Moulton, L. L., Doucette, P. J., and Tagestad, J. D.: Use of synthetic aperture radar to identify and characterize overwintering areas of fish in ice-covered arctic rivers: a demonstration with broad whitefish and their habitats in the Sagavanirktok River, Alaska, T. Am. Fish. Soc., 139, 1711-1722, 2010.

Callaghan, T. V., Johansson, M., Brown, R. D., Groisman, P. Y., Labba, N., Radionov, V., Bradley, R. S., Blangy, S., Bulygina, O. N., Christensen, T. R., Colman, J. E., Essery, R. L. H., Forbes, B. C., Forchhammer, M. C., Golubev, V. N., Honrath, R. E., Juday, G. P., Meshcherskaya, A. V., Phoenix, G. K., Pomeroy, J., Rautio, A., Robinson, D. A., Schmidt, N. M., Serreze, M. C., Shevchenko, V. P., Shiklomanov, A. I., Shmakin, A. B., Sköld, P., Sturm, M., Woo, M.-K., and Wood, E. F.: Multiple effects of changes in arctic snow cover, Ambio, 40, 32-45, 2011.
Clausi, A., Qin, A. K., Chowdhury, M. S., Yu, P., and Maillard, P.: MAGIC: Map-Guided Ice Classification System, Can. J. Remote Sens., 36, S13-S25, 2010.

Comiso, J. C., Parkinson, C. L., Gersten, R., and Stock, L.: Accelerated decline in the Arctic sea ice cover, Geophys. Res. Lett., 35 , doi:10.1029/2007GL031972, 2008.

Cook, T. L. and Bradley, R. S.: An analysis of past and future changes in the ice cover of two High-Arctic lakes based on synthetic aperture radar (SAR) and Landsat imagery, Arct. Antarct. Alp. Res., 42, 9-18, 2010.

Dufresne, J.-L., Foujols, M.-A., Denvil, S., Caubel, A., Marti, O., Aumont, O, Balkanski, Y., Bekki, S., Bellenger, H., Benshila, R., Bony, S., Bopp, L., Braconnot, P., Brockmann, P., Cadule, P., Cheruy, F., Codron, F., Cozic, A., Cugnet, D., de Noblet, N., Duvel, J.-P., Ethé, C., Fairhead, L., Fichefet, T., Flavoni, S., Friedlingstein, P., Grandpeix, J.-Y.., Guez, L., Guilyardi, E., Hauglustaine, D., Hourdin, F., Idelkadi, A., Ghattas, J., Joussaume, S., Kageyama, M., Krinner, G., Labetoulle, S., Lahellec, A., Lefebvre, M.-P., Lefevre, F., Levy, C., Li, Z.X., Lloyd, J., Lott, F., Madec, G., Mancip, M., Marchand, M., Masson, S., Meurdesoif, Y., Mignot, J., Musat, I., Parouty, S., Polcher, J., Rio, C., Schulz, M., Swingedouw, D., Szopa, S., Talandier, C., Terray, P., and Viovy, N.: Climate change projections using the IPSL-CM5 Earth System Model: from CMIP3 to CMIP5, Clim. Dynam., 40, 2123-2165, 2013.

Duguay, C. R. and Lafleur, P. M.: Determining depth and ice thickness of shallow subarctic lakes using spaceborne optical and SAR data, Int. J. Remote Sens., 24, 475-489, 2003.

Duguay, C. R., Rouse, W. R., Lafleur, P. M., Boudreau, D. L., Crevier, Y., and Pultz, T. J.: Analysis of multi-temporal ERS-1 SAR data of subarctic tundra and forest in the northern Hudson Bay Lowland and implications for climate studies, Can. J. Remote Sens., 25, 21-33, 1999.

Duguay, C. R., Pultz, T. J., Lafleur, P. M., and Drai, D.: RADARSAT backscatter characteristics of ice growing on shallow sub-Arctic lakes, Churchill, Manitoba, Canada, Hydrol. Process., 16, 16311644, 2002.

Duguay, C. R., Flato, G. M., Jeffries, M. O., Ménard, P., Morris, K., and Rouse, W. R.: Ice-cover variability on shallow lakes at high latitudes: model simulations and observations, Hydrol. Process., 17, 3465-3483, 2003.

Duguay, C. R., Prowse, T. D., Bonsal, B. R., Brown, R. D., Lacroix, M. P., and Ménard, P.: Recent trends in Canadian lake ice cover, Hydrol. Process., 20, 781-801, 2006.

Duguay, C., Brown, L., Kang, K.-K., and Kheyrollah Pour, H.: The Arctic lake ice, in "State of the climate in 2011", B. Am. Meteorol. Soc., 93, S152-S154, 2012.

Elachi, C. M., Bryan, M. L., and Weeks, W. F.: Imaging radar observations of frozen Arctic lakes, Remote Sens. Environ., 5, 169175, 1976.

Engram, M., Anthony, K. W., Meyer, F. J., and Grosse, G.: Characterization of L-band synthetic aperture radar (SAR) backscatter from floating and grounded thermokarst lake ice in Arctic Alaska, The Cryosphere, 7, 1741-1752, doi:10.5194/tc-7-17412013, 2013.

Futter, M. N.: Patterns and trends in southern Ontario lake ice phenology, Environ. Monit. Assess., 88, 431-444, 2003. 
Gao, S. and Stefan, H. G.: Potential climate change effects on ice covers of five freshwater lakes, J. Hydrol. Eng., 9, 226-234, 2004.

Grosswald, M. G., Hughes, T. J., and Lasca, N. P.: Oriented lakeand-ridge assemblages of the Arctic coastal plains: glacial landforms modified by thermokarst and solifluction, Polar Rec., 35, 215-230, 1999.

Hall, D. K., Fagre, D. B., Klasner, F., Linebaugh, G., and Liston, G. E.: Analysis of ERS 1 synthetic aperture radar data of frozen lakes in northern Montana and implications for climate studies, J. Geophys. Res., 99, 22473-22482, 1994.

Hartmann, B. and Wendler, G.: The significance of the 1976 Pacific climate shift in the climatology of Alaska, J. Climate, 18, 48244839, 2005.

Heron, R. and Woo, M. K.: Decay of a High Arctic lake-ice cover: Observations and modelling, J. Glaciol., 40, 283-292, 1994.

Hinkel, K. M., Nelson, F. E., Klene, A. F., and, Bell, J. H.: The urban heat island in winter at Barrow, Alaska, Int. J. Climatol., 23, 1889-1905, 2003.

Hinkel, K. M., Frohn, R. C., Nelson, F. E., Eisner, W. R., and Beck, R. A.: Morphometric and spatial analysis of thaw lakes and drained thaw lake basins in the western Arctic Coastal Plain, Alaska, Permafrost Periglac., 16, 327-341, 2005.

Hinkel, K. M., Jones, B. M., Eisner, W. R., Cuomo, C. J., Beck, R. A., and Frohn, R. C.: Methods to assess natural and anthropogenic thaw lake drainage on the western Arctic Coastal Plain of northern Alaska, J. Geophys. Res., 112, F02S16, doi:10.1029/2006JF000584, 2007.

Hinkel, K. M., Zheng, L., Yongwei, S., and Evan, A.: Regional lake ice meltout patterns near Barrow, Alaska, Polar Geogr., 35, 1-18, 2012.

Hodgkins, G. A., James, I. C., and Huntington, T. G.: Historical changes in lake ice-out dates as indicators of climate change in New England, 1850-2000, Int. J. Climatol., 22, 1819-1827, 2002.

Hurrell, J. W.: Influence of variations in extratropical wintertime teleconnections on Northern Hemisphere temperature, Geophys. Res. Lett., 23, 665-668, 1996.

Jeffries, M. O. and Morris, K.: Some aspects of ice phenology on ponds in central Alaska, USA, Ann. Glaciol., 46, 397-403, 2007.

Jeffries, M. O., Morris, K., Weeks, W. F., and Wakabayashi, H.: Structural and stratigraphic features and ERS 1 synthetic aperture radar backscatter characteristics of ice growing on shallow lakes in NW Alaska, winter 1991-1992, J. Geophys. Res., 99, 22459 22471, 1994.

Jeffries, M. O., Morris, K., and Liston, G. E.: A method to determine lake depth and water availability on the North Slope of Alaska with spaceborne imaging radar and numerical ice growth modelling, Arctic, 49, 367-374, 1996.

Jeffries, M. O., Zhang, T., Frey, K., and Kozlenko, N.: Estimating late winter heat flow to the atmosphere from the lake-dominated Alaskan North Slope, J. Glaciol., 45, 315-324, 1999.

Jeffries, M. O., Morris, K., and Kozlenko, N.: Ice characteristics and processes, and remote sensing of frozen rivers and lakes, in: Remote Sensing in Northern Hydrology: Measuring Environmental Change, edited by: Duguay, C. R. and Pietroniro, A., Washington, American Geophysical Union, 63-90, 2005.

Jones, B. M., Arp, C. D., Hinkel, K. M., Beck, R. A., Schmutz, J. A., and Winston, B.: Arctic lake physical processes and regimes with implications for winter water availability and management in the National Petroleum Reserve Alaska, Environ. Manage., 43, 1071-1084, 2009.

Jones, B. M., Grosse, G., Arp, C. D., Jones, M. C., Walter, A. K. M., and Romanovsky, V. E.: Modern thermokarst lake dynamics in the continuous permafrost zone, northern Seward Peninsula, J. Geophys. Res., 16, G00M03, doi:10.1029/2011JG001666, 2011.

Jones, B. M., Gusmeroli, M. A., Arp, C. D., Strozzi, T., Grosse, G., Gaglioti, B. V., and Whitman, B. S.: Classification of freshwater ice conditions on the Alaskan Arctic Coastal Plain using ground penetrating radar and TSX satellite data, Int. J. Remote Sens., 34, 8253-8265, 2013.

Kaufman, D. S., Schneider, D. P., McKay, N. P., Ammann, C. M., Bradley, R. S., Briffa, K. R., and Thomas, E.: Recent warming reverses long-term Arctic cooling, Science, 325, 1236-1239, 2009.

Koenigk, T., Brodeau, L., Graversen, R. G., Karlsson, J., Svensson, G., Tjernström, M., and Willén, K.: Arctic climate change in 21st century CMIP5 simulations with EC-Earth, Clim. Dynam., 40, 2719-2743, 2013.

Labrecque, S., Lacelle, D., Duguay, C. R., Lauriol, B., and Hawkings, J.: Contemporary (1951-2001) evolution of lakes in the Old Crow Basin, northern Yukon, Canada: Remote sensing, numerical modeling, and stable isotope analysis, Arctic, 62, 225-238, 2009.

Latifovic, R. and Pouliot, D.: Analysis of climate change impacts on lake ice phenology in Canada using the historical satellite data record, Remote Sens. Environ., 106, 492-507, 2007.

Lenormand, F., Duguay, C. R., and Gauthier, R.: Development of a historical ice database for the study of climate change in Canada, Hydrol. Process., 16, 3707-3722, 2002.

Liston, G. E., and Sturm, M.: Winter precipitation patterns in arctic Alaska determined from a blowing-snow model and snow-depth observations, J. Hydrometeorol., 3, 646-659, 2002.

Magnuson, J. J., Robertson, D. M., Benson, B. J., Wynne, R. H., Livingstone, D. M., Arai, T., Assel, R. A., Barry, R. G., Virginia Card, V., Kuusisto, E., Granin, N. G., Prowse, T. D., Stewart, K. M., and Vuglinski, V. S.: Historical trends in lake and river ice cover in the Northern Hemisphere, Science, 289, 1743-1746, 2000.

Mellor, J.: Bathymetry of Alaskan Arctic lakes: A key to resource inventory with remote sensing methods, $\mathrm{Ph}$. D. Thesis, Institute of Marine Science, University of Alaska, 1982.

Ménard, P., Duguay, C. R., Flato, G. M., and Rouse, W. R.: Simulation of ice phenology on Great Slave Lake, Northwest Territories, Canada, Hydrol. Process., 16, 3691-3706, 2002.

Mendez, J., Hinzman, L. D., and Kane, D. L.: Evapotranspiration from a wetland complex on the Arctic coastal plain of Alaska, Nord. Hydrol., 29, 303-330, 1998.

Morris, K., Jeffries, M. O., and Weeks, W. F.: Ice processes and growth history on Arctic and sub-Arctic lakes using ERS-1 SAR data, Polar Rec., 31, 115-128, 1995.

Morris, K., Jeffries, M. O., and Duguay, C.: Model simulation of the effects of climate variability and change on lake ice in central Alaska, USA, Ann. Glaciol., 40, 113-118, 2005.

National Climate Data Center (NCDC): Barrow, retrieved from http: //www.ncdc.noaa.gov/cdo-web/datasets/ANNUAL/locations (last access: 28 April 2013), 2012. 
Noguchi, K., Gel, Y. R., and Duguay, C. R.: Bootstrap-based test for trends in hydrological times series, with application to ice phenology data, J. Hydrol., 410, 150-161, 2011.

Ochilov, S., Svacina, N. A., Duguay, C. R., and Clausi, D. A.: Towards an automated lake ice monitoring system for SAR imagery, Abstract C51A-0474 presented at the 2010 Fall Meeting, AGU, San Francisco, Calif., 13-17 December, 2010.

Overland, J. E., Wang, M., Walsh, J. E., Christensen, J. H., Kattsov, V. M., and Chapman W. L.: Chapter 3: Climate model projections for the Arctic, Snow, Water, Ice and Permafrost in the Arctic (SWIPA), Oslo, Arctic Monitoring and Assessment Programme (AMAP), 2011.

Palecki, M. A. and Barry, R. G.: Freeze-up and break-up of lakes as an index of temperature changes during the transition seasons: A case study for Finland, J. Clim. Appl. Meteorol., 25, 893-902, 1986.

Prowse, T., Alfredsen, K., Beltaos, S., Bonsal, B., Duguay, C., Korhola, A., McNamara, J., Vincent, W. F., Vuglinsky, V., and Weyhenmeyer, G. A.: Arctic freshwater ice and its climatic role, Ambio, 40, 46-52, doi:10.1007/s13280-011-0214-9, 2011.

Robertson, D. M., Ragotzkie, R. A., and Magnuson, J. J.: Lake ice records used to detect historical and future climatic changes, Clim. Change, 21, 407-427, 1992.

Romanovsky, V. E., Smith, S. L., and Christiansen, H. H.: Permafrost thermal state in the polar Northern Hemisphere during the International Polar Year 2007-2009: A synthesis, Permafrost Periglac., 21, 106-116, 2010.

Rovansek, R. J., Hinzman, L. D., and Kane, D. L.: Hydrology of a tundra wetland complex in the Alaskan Arctic coastal plain, USA., Arctic Alpine Res., 28, 311-317, 1996.

Schindler, D. W. and Smol, J. P.: Cumulative effects of climate warming and other human activities on freshwaters of Arctic and Subarctic North America, Ambio, 35, 160-168, 2006.

Schindler, D. W., Beaty, K. G., Fee, E. J., Cruikshank, D. R., DeBruyn, E. R., Findlay, D. L., and Turner, M. A.: Effects of climatic warming on lakes of the central boreal forest, Science, 250 , 967-970, 1990.

Sellmann, P. V., Weeks, W. F., and Campbell, W. J.: Use of sidelooking airborne radar to determine lake depth on the Alaskan North Slope, CRREL Special Report (US Army Cold Regions Research and Engineering Laboratory), 230, 1975.

Sen, P. K.: Estimates of the regression coefficient based on Kandall's tau, J. Am. Stat. Assoc., 63, 1379-1389, 1968.

Serreze, M. C., Walsh, J. E., Chapin III, F. S., Osterkamp, T., Dyurgerov, M., Romanovsky, V., Oechel, W. C., Morison, J., Zhang, T., and Barry, R. G.: Observational evidence of recent change in the northern high-latitude environment, Clim. Change, 46, 159-207, 2000.

Serreze, M. C., Holland, M. M., and Stroeve, J.: Perspectives on the Arctic's shrinking sea-ice cover, Science, 315, 1533-1536, 2007.

Smith, L. C., Sheng Y., MacDonald, G. M., and Hinzman, L. D.: Disappearing Arctic lakes, Science, 308, p. 1429, doi:10.1126/science.1108142, 2005.

Smol, J. P. and Douglas, M. S. V.: Crossing the final ecological threshold in High Arctic ponds, P. Natl. Acad. Sci. USA, 104, 12395-12397, 2007.
Sobiech, J. and Dierking, W.: Monitoring lake-ice decay with imaging radar in the Siberian Arctic, International Symposium on Seasonal Snow and Ice, Lahti, Finland, 28 May 2012-1 June 2012, 2012.

Sturm, M. and Liston, G. E.: The snow cover on lakes of the Arctic Coastal Plain of Alaska, USA., J. Glaciol., 49, 370-380, 2003.

Trenberth, K. E., Jones, P. D., Ambenje, P., Bojariu, R., Easterling, D., Klein Tank, A., Parker, D., Rahimzadeh, F., Renwick, J. A., Rusticucci, M., Soden, B., and Zhai, P.: Observations: Surface and Atmospheric Climate Change, in: Climate Change 2007: The Physical Science Basis. Contribution of Working Group I to the Fourth Assessment Report of the Intergovernmental Panel on Climate Change, edited by: Solomon, S., Qin, D., Manning, M., Chen, Z., Marquis, M., Averyt, K. B., Tignor, M., and Miller, H. L., Cambridge University Press, Cambridge, United Kingdom and New York, NY, USA, 2007.

Vavrus, S. J., Wynne, R. H., and Foley, J. A.: Measuring the sensitivity of Southern Wisconsin lake ice to climate variations and lake depth using a numerical model, Limnol. Oceanogr., 41, 822-831, 1996.

Walsh, S. E., Vavrus, S. J., Foley, J. A., Fisher, V. A., Wynne, R. H., and Lenters, J. D.: Global patterns of lake ice phenology and climate: Model simulations and observations, J. Geophys. Res.Atmos., 103, 28825-28837, 1998.

Walsh, J. E., Overland, J. E., Groisman, P. Y., and Rudolf, B.: Chapter 2: Arctic climate: Recent variations, Snow, Water, Ice and Permafrost in the Arctic (SWIPA), Oslo, Arctic Monitoring and Assessment Programme (AMAP), 2011.

Walter, K. M., Zimov, S. A., Chanton, J. P., Verbyla, D., and Chapin III, F. S.: Methane bubbling from Siberian thaw lakes as a positive feedback to climate warming, Nature, 443, 71-75 doi:10.1038/nature05040, 2006.

Walter, K. M., Engram, M., Duguay, C. R., Jeffries, M. O., and Chapin, F. S.: The potential use of synthetic aperture radar for estimating methane ebullition from Arctic lakes, J. Am. Water. Resour. As., 44, 305-315, 2008.

Weeks, W. F., Fountain, A. G., Bryan, M. L., and Elachi, C.: Differences in radar returns from ice-covered North Slope lakes, J. Geophys. Res., 83, 4069-4073, 1978.

Wendler, G., Chen, L., and Moore, B.: The First decade of the new century: a cooling trend for most of Alaska, The Open Atmospheric Science Journal, 6, 111-116, 2012.

White, D. M., Prokein, P., Chambers, M. K., Lilly, M. R., and Toniolo, H.: Use of synthetic aperture radar for selecting Alaskan lakes for winter water use, J. Am. Water. Resour. As., 44, 276284, 2008.

Young, K. L. and Woo, M. K.: Hydrological response of a patchy high arctic wetland, Nord. Hydrol., 31, 317-338, 2000.

Zhang, T. and Jeffries, M. O.: Modeling interdecadal variations of lake ice thickness and sensitivity to climatic change in northernmost Alaska, Ann. Glaciol., 31, 339-347, 2000. 